\title{
Catalytic control of diesel engine particulate emission: Studies on model reactions over a EuroPt-1 $\left(\mathrm{Pt} / \mathrm{SiO}_{2}\right)$ catalyst
}

\author{
E Xue, K. Seshan and J.G van Ommen \\ Faculty of Chemical Technology, University of Twente, 7500 AE Enschede (Netherlands) \\ and \\ J R H Ross \\ Department of Industrial Chemistry and Life Sciences, University of Limerick (Ireland)
}

(Received 9 September 1992, revised manuscript received 1 February 1993)

\begin{abstract}
The catalytic oxidation of nitric oxide to nitrogen dioxide in the presence of sulphur dioxide over a standard $\mathrm{Pt} / \mathrm{SiO}_{2}$ catalyst (EuroPt-1) was studied The gas-phase reactions between nitric oxide, sulphur dioxide and oxygen were found to be insignificant under the expenmental conditions concerned The $\mathrm{Pt} / \mathrm{StO}_{2}$ catalyst was observed to be very active in catalyzing the reactions both of $\mathrm{NO}+\mathrm{O}_{2}$ to $\mathrm{NO}_{2}$ and of $\mathrm{SO}_{2}+\mathrm{O}_{2}$ to $\mathrm{SO}_{3}$ In the presence of sulphur dioxide, the catalytic activity for nitnc oxide oxidation dropped dramatically, and in contrast, the presence of nitric oxide promoted sulphur dioxide oxidation There is significant influence of $\mathrm{NO} / \mathrm{NO}_{2}$ on sulphur dioxide oxidation, there are indications from temperature-programmed desorption and temperature-programmed reduction (TPR) that some sort of complex species (eg $\left[\mathrm{N}_{x}-\mathrm{S}_{y}-\mathrm{O}_{z}\right]$ ) is formed on the platinum surface Deactivation of the catalyst was also observed durng the activity tests it is believed that the deactivation of the catalyst was mainly caused by the buld-up of some nitrogen and sulphur compounds on the active sites of the platinum catalyst Another reason for the deactivation could be the sintenng of platinum particles in the reaction environment This has been confirmed by X-ray photoelectron spectroscopy, TPR and platınum dispersion measurements
\end{abstract}

Keywords deactivation, diesel particulate removal, EuroPt-1, nitnc oxide oxidation, nitrogen dioxıde, nitrogen dioxide and sulphur dioxide interaction, platınum/slica, sulphur dioxıde, sulphur dioxide oxıdation

\section{INTRODUCTION}

Increasing concern for our environment has led to stricter legislative requirements worldwide on the emission of pollutants Technical control of the

Correspondence to Dr E Xue or Dr K Seshan, Faculty of Chemical Technology, University of Twente, P 0 Box 217, 7500 AE Enschede, Netherlands Tel (+31-53)892225, fax (+3153)356024 
exhaust emission from automobiles, such as unburnt hydrocarbons (HCs), carbon monoxide, nitrogen oxıdes $\left(\mathrm{NO}_{x}\right)$ and particulate matter, has become a topic of current major interest The emission from a diesel engine generally consists of two phases, gaseous and solid The major pollutants in the gas phase are unburnt $\mathrm{HCs}, \mathrm{CO}, \mathrm{NO}_{x}$ and sulphur oxides $\left(\mathrm{SO}_{x}\right)$ The concentration levels of the HCs and carbon monoxide in diesel engine exhaust, depend on the type of diesel fuel, on the diesel engine, and on its working conditions, but are generally considerably lower than those from a gasolıne-powered engine $\mathrm{The}^{\mathrm{NO}} \mathrm{x}_{x}$ concentration is also generally significantly lower The solid phase or the socalled 'soot', which is typical of diesel exhausts, contains fine particulates and is at a level much higher than that emitted from a gasoline-powered engine The soot, which is formed as a consequence of the way in which the diesel fuel burns inside the engine, consists of carbon and adsorbed materials such as unburnt hydrocarbons, sulphates and metals Since the soot emitted is potentially carcinogenic [1], stringent legislation requiring reduction of its emission has been proposed in many countries Among the technologies currently avallable, modification of the design of the diesel engine alone is insufficient to meet the emission standards likely to be introduced in the near future [1] Posttreatment of the exhaust will therefore be required and catalytic converters are thus likely to play an essential role in the reduction of the soot emission

One possible catalytic process would use an oxidative catalytic converter [2], the $\mathrm{NO}_{x}$ present in the oxygen rich exhaust would be catalytically oxidized to nitrogen dioxide which can then oxidize the soot to the less harmful carbon dioxide. Noble metals such as platınum have been used successfully in threeway catalysts to control the exhaust emissions from gasoline-powered engines Recent studies [3,4] have also shown that platınum catalysts are capable of oxıdızıng soot partıculates as well as carbon monoxide and $\mathrm{HCs}$, particularly at relatively low temperatures Unfortunately, the sulphur dioxide present in the diesel exhaust is also oxidized over these platınum catalysts to $\mathrm{SO}_{3}$, this $\mathrm{SO}_{3}$ in turn forms sulphates which are adsorbed on the soot and this leads to an apparent increase in the weight of the soot emitted In order to develop suitable diesel exhaust clean-up catalysts, it is therefore essential to understand the catalytic reactions involved in the oxidation of nitric oxide to nitrogen dioxide in the presence of sulphur dioxide over platınum catalysts

In the work reported in this paper, we have studied the catalytic behaviour of a standard $\mathrm{Pt} / \mathrm{SiO}_{2}$ catalyst (EuroPt-1) [5] for the oxidation of nitric oxide to nitrogen dioxide and of sulphur dioxide to $\mathrm{SO}_{3}$ under simulated diesel exhaust conditions The study aims at gaining an understanding of the behaviour of Pt-based catalyst in the oxidation of $\mathrm{NO}_{x}$ and $\mathrm{SO}_{x}$ as well as the interaction between $\mathrm{NO}_{x}$ and $\mathrm{SO}_{x}$ on the catalyst surface, in order to be able to predict a possible reaction mechanism, and to develop catalysts with which the nitric oxide can be oxıdized selectively 
EXPERIMENTAL

\section{Catalyst}

A standard $\mathrm{Pt} / \mathrm{SiO}_{2}$ catalyst EuroPt- 1 was used in this study This catalyst contains $63 \mathrm{wt}-\%$ platınum with a platinum dispersion 065 It has a surface area $185 \mathrm{~m}^{2} \mathrm{~g}^{-1}$ and was used in the form of grains with a size ranging from 01 to $05 \mathrm{~mm}$ The EuroPt-1 catalyst has been well characternzed, detalls are to be found in ref 5 A pure $\mathrm{SiO}_{2}$ (Fluid Silica F-7, from Akzo Chemie b v, the Netherlands) with surface area of $285 \mathrm{~m}^{2} \mathrm{~g}^{-1}$, was employed as a reference support material in the study In the following text, the term fresh refers to the "as-received" EuroPt-1 catalyst; the term used implies the catalyst which had been used for an activity test, the red-used means a used catalyst which was reduced in $5 \% \mathrm{H}_{2}$ at $400^{\circ} \mathrm{C}$ for $2 \mathrm{~h}$, and $\mathrm{Cl}$-used is a used catalyst which was subjected to a treatment with $05 \mathrm{M} \mathrm{HCl}$ followed by calcination at $500^{\circ} \mathrm{C}$ for $2 \mathrm{~h}$

\section{Actzvity measurements}

The activity experiments were carried out in a fixed-bed reactor system The gas composition and flow were controlled by mass flow controllers and rechecked by a flow meter before the vent $A$ nitrogen oxides analyzer (Model 8840 , Monitor Labs Inc , USA) was used to measure contınuously the concentrations of nitric oxide and nitrogen dioxide The sulphur dioxide concentration was monitored on line by a Defor $\mathrm{SO}_{2}$ analyzer (Maihak GmbH, Germany) The experimental parameters such as reaction temperature, flow and concentrations of inlet gas were controlled by a computer programme and monitored by an Apple Ile computer connected to the experimental system All the gases used in the experiments were of high purity grade The exper1mental system was calibrated before starting each experıment The conversions of both nitric oxide and sulphur dioxide were determined by measuring the concentration changes between the inlet and outlet of the reactor

The activity tests were carried out in the temperature range from 200 to $400^{\circ} \mathrm{C}$ under atmosphere pressure The catalyst load in the reactor was 200 $\mathrm{mg}$, and the gas flow used was $241 \mathrm{~h}^{-1}$ (normal temperature and pressure) The concentrations used in the inlet gas stream during the activity experiments were $\mathrm{NO} 500 \mathrm{ppm}$ and/or $\mathrm{SO}_{2} 50 \mathrm{ppm}, \mathrm{O}_{2} 10 \%$, and balance nitrogen, which corresponded to those in a typical diesel exhaust In some of the measurements the experımental parameters were changed slightly, these changes will be noticed in appropriate places in the text 
Temperature-programmed desorption/temperature-programmed reduction/ platinum dispersion

Temperature-programmed desorption (TPD) experiments were conducted in the same set-up as that used for the activity measurements The pre-treating gas mixture was first passed over the catalyst bed at the reaction temperatures $\left(200\right.$ to $\left.400^{\circ} \mathrm{C}\right)$ The catalyst was then cooled to room temperature in the same gas stream, and the catalyst bed was purged in nitrogen for about one hour After the signals for the nitric oxide, nitrogen dioxide and/or sulphur dioxide from the detectors had dropped to zero, TPD was started in nitrogen stream with a flow of $24 \mathrm{l} \mathrm{h}^{-1}$ (normal temperature and pressure) using a heating rate of $10 \mathrm{~K} \mathrm{~min}^{-1}$ The concentrations of the desorbed nitric oxide, nitrogen dioxIde and/or sulphur dioxide were recorded as a function of temperature

Temperature-programmed reduction (TPR) experiments were carried out in a conventional TPR set-up using a mixture of $5 \% \mathrm{H}_{2} \mathrm{in} \mathrm{Ar}$ as the reducing gas; the hydrogen consumption was continuously measured by a thermal conductivity detector (TCD) The gas volume flow was $20 \mathrm{ml} \mathrm{min}^{-1}$ and the heating rate was $10 \mathrm{~K} \mathrm{~min}^{-1}$

Platınum dispersions was determined by the hydrogen/oxygen chemisorption-titration technique [6] This involved pre-reducing the catalyst at $400^{\circ} \mathrm{C}$, followed alternatively by hydrogen and oxygen pulse titration at room temperature $\mathrm{A} \mathrm{Pt:H}$ stoichiometry of 11 was used for calculating the platinum dispersıon. The experiments were performed with a Pulse ChemiSorb 2700 (M1cromeritics Ltd , USA)

\section{RESULTS AND DISCUSSION}

\section{Gas-phase reactions}

To examine the extent of the gas-phase reactions in nitric oxide, sulphur dioxide and oxygen mixture under the experimental condition concerned, experiments with varying gas compositions and at different reaction temperatures were carried out with an empty reactor The results showed that the degree of oxidation of nitric oxide with oxygen in the experimental system without a catalyst, under the conditions used, was about $8 \%$ in the absence of sulphur dioxide and that the conversion was independent of the reactor temperature This invariance with temperature was probably caused by reaction on the interconnecting stainless-steel tubing [7] used in the reactor system, as this was all kept at a constant temperature of $100^{\circ} \mathrm{C}$ during the activity measurements The gas-phase oxidation of sulphur dioxide with oxygen was observed to be about $2 \%$ at $350^{\circ} \mathrm{C}$ in the absence of nitric oxide and this increased to $4 \%$ in the presence of nitric oxide, in the presence of both nitric oxıde and nitrogen dioxide, the sulphur dioxide conversion reached $6 \%$ at $350^{\circ} \mathrm{C}$ 


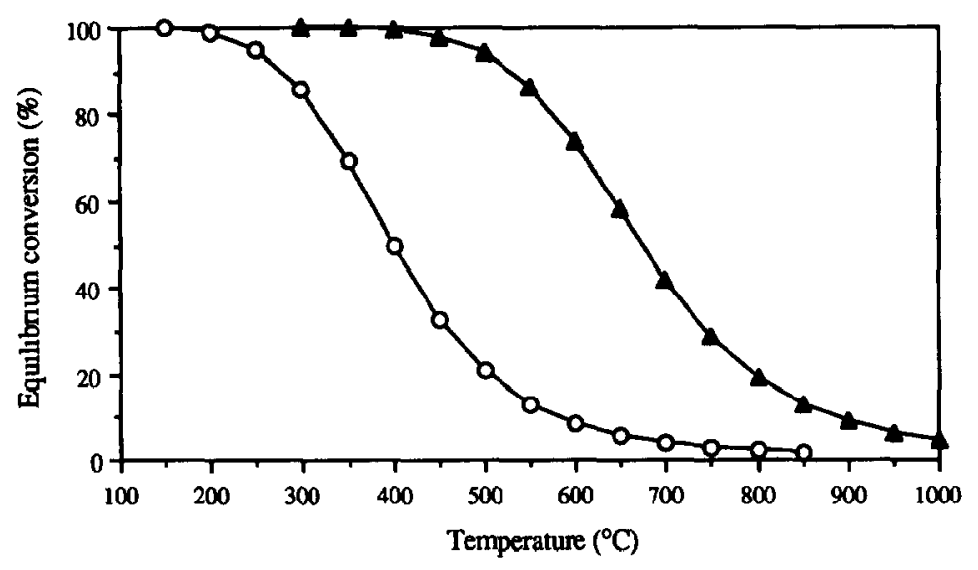

Fig 1 Equilibnum conversion for oxidation of nitric oxide and sulphur dioxide with oxygen, calculation conditions used are $\mathrm{NO}=500 \mathrm{ppm}, \mathrm{SO}_{2}=50 \mathrm{ppm}, \mathrm{O}_{2}=10 \%$, total pressure 1 bar (O) NO conversion, $(\Delta) \mathrm{SO}_{2}$ conversion

These results indicated that the presence of $\mathrm{NO}_{x}$ catalyses the oxidation of sulphur dioxide with oxygen to a relatively small extent under our experimental conditions, despite the fact that $\mathrm{NO}_{x}$ was used as a catalyst for sulphur dioxide oxidation in the Lead Chamber Process [8]

To identify any thermodynamic limitations to the reactions concerned, calculations of the equilibrium conversions under the experimental conditions were performed using the Aspen Plus program, and the results are plotted in Fig 1 It can be seen that nitric oxide oxidation is thermodynamically favourable at lower temperatures but that nitric oxide cannot be completely oxıdized to nitrogen dioxide when the temperature is higher than $250^{\circ} \mathrm{C}$; for sulphur dioxide oxidation, the equilibrium conversion starts to go down at temperatures above $400^{\circ} \mathrm{C}$

\section{Catalytic activities}

Typical results from the actıvity measurements at $300^{\circ} \mathrm{C}$ and $350^{\circ} \mathrm{C}$, under different inlet gas compositions and over differently treated EuroPt-1 catalysts, are summarized in Table 1 The data in Table 1 will be used for discussion in the text wherever appropriate The activity data measured over pure $\mathrm{SiO}_{2}$ are also listed in Table 1 for reference Figs. $2 a$ and $b$ show typical data as a function of reaction temperature Fig. 2a shows the typical results of nitric oxide conversion as a function of temperature, in the presence and absence of sulphur dioxide. It can be seen that EuroPt-1 is very active in catalyzing the reaction of $\mathrm{NO}+\mathrm{O}_{2}$ to $\mathrm{NO}_{2}$ In the absence of sulphur dioxide, equilibrium conversion of nitric oxide can be acheved at temperatures above $350^{\circ} \mathrm{C}$ (dotted line in Fig 2a indicates the equilibrium conversion of nitmc oxide), how- 
TABLE 1

Nitrix oxıde and sulphur dioxıde conversıons (\%) over EuroPt-1 catalysts after different treatments

\begin{tabular}{|c|c|c|c|c|c|c|c|c|}
\hline \multirow{2}{*}{$\begin{array}{l}\text { Test gas mixture } \\
\text { Conversion } \\
(\%)^{\circ} \\
\text { Temperature } \\
\left({ }^{\circ} \mathrm{C}\right)\end{array}$} & \multicolumn{2}{|l|}{$\begin{array}{l}\mathrm{NO}+\mathrm{O}_{2} \\
X_{\mathrm{NO}}\end{array}$} & \multicolumn{2}{|c|}{$\begin{array}{l}\mathrm{NO}+\mathrm{SO}_{2}+\mathrm{O}_{2} \\
X_{\mathrm{NO}}\end{array}$} & \multicolumn{2}{|c|}{$\begin{array}{l}\mathrm{SO}_{2}+\mathrm{O}_{2} \\
X_{\mathrm{SO}_{2}}\end{array}$} & \multicolumn{2}{|c|}{$\begin{array}{l}\mathrm{NO}+\mathrm{SO}_{2}+\mathrm{O}_{2} \\
X_{\mathrm{SO}_{2}}\end{array}$} \\
\hline & 300 & 350 & 300 & 350 & 300 & 350 & 300 & 350 \\
\hline $\mathrm{S}_{1} \mathrm{O}_{2}$ & 3 & 6 & 3 & 6 & - & & 2 & 3 \\
\hline fresh & 60 & 67 & 24 & 44 & 23 & 65 & 75 & 97 \\
\hline used $^{b}$ & 53 & 61 & 20 & 38 & $45^{c}$ & $85^{c}$ & 66 & 95 \\
\hline red-used & $83 \rightarrow 46^{d}$ & 60 & - & - & 52 & 100 & $86 \rightarrow 77^{\mathrm{c}}$ & 98 \\
\hline Cl-used & 41 & 57 & 29 & 47 & 40 & 80 & 40 & 70 \\
\hline
\end{tabular}

${ }^{a} X_{\mathrm{NO}} \mathrm{NO}$ conversion, $X_{\mathrm{SO}_{2}} \mathrm{SO}_{2}$ conversion

${ }^{b}$ The term used here refers to the catalyst which had been in the test gas mixture of $\mathrm{NO}, \mathrm{SO}_{2}$ and $\mathrm{O}_{2}$ for approximately $40 \mathrm{~h}$ under the reaction conditions

"These data were obtamed with the catalyst after being used for the test reaction $\mathrm{NO}+\mathrm{O}_{2}$

${ }^{d}$ Since the hydrogen reduction only improves the activity temporarily, the values in the beginning and in the steady state are given

ever, the presence of sulphur dioxıde in the feed gas suppresses the nitric oxıde oxidation remarkably (see also the data in Table 1) Typical results of sulphur dioxide conversion as function of the reaction temperature over EuroPt-1 catalyst, both in the presence and in the absence of nitric oxide, are shown in Fig $2 \mathrm{~b}$ The EuroPt-1 catalyst shows also very high activity for sulphur dioxıde oxidation and the conversion of sulphur dioxide becomes even greater in the presence of nitric oxide (see also the data in Table 1)

It has been reported that the presence of sulphur dioxide inhibits nitric oxide conversion in the catalytic decomposition of nitric oxide with ammonia over platinum catalysts [9] The inhibition effect of sulphur dioxide on the nitric oxide oxıdation was also observed by Karisson and Rosenberg [10] for $\mathrm{Cu}-$ zeolite However, the work of Teraoka et al [11] on Pt/ZSM-5 has shown that the presence of sulphur dioxide did not affect nitric oxide oxidation Arai et al [12] have found in their study that the presence of sulphur dioxide and water enhances nitric oxide oxidation over a $\mathrm{Cr}^{\mathrm{III}}$-zeolite catalyst $\mathrm{On}$ the other hand, the positive effect of nitric oxide on sulphur dioxide oxidation is known KarIsson and Rosenberg [10] observed complete sulphur dioxide oxidation when nitric oxide and oxygen were present in the feed gas over a $\mathrm{Pt} / \mathrm{Al}_{2} \mathrm{O}_{3}$ catalyst A similar positive effect of nitric oxıde on sulphur dioxide oxidation over $\mathrm{V}_{2} \mathrm{O}_{5}$ $\mathrm{MoO}_{3} / \mathrm{TiO}_{2}$ catalyst has also been reported by Teraoka et al [11] Nitric oxıde is also known as a catalyst for sulphur dioxide oxidation in Lead Chamber Process [8] The results of the present study clearly indicate that the presence of sulphur dioxide, even in a very low concentration, could suppress remarkably the nitric oxide oxidation under the conditions used, and that the presence 
(a)

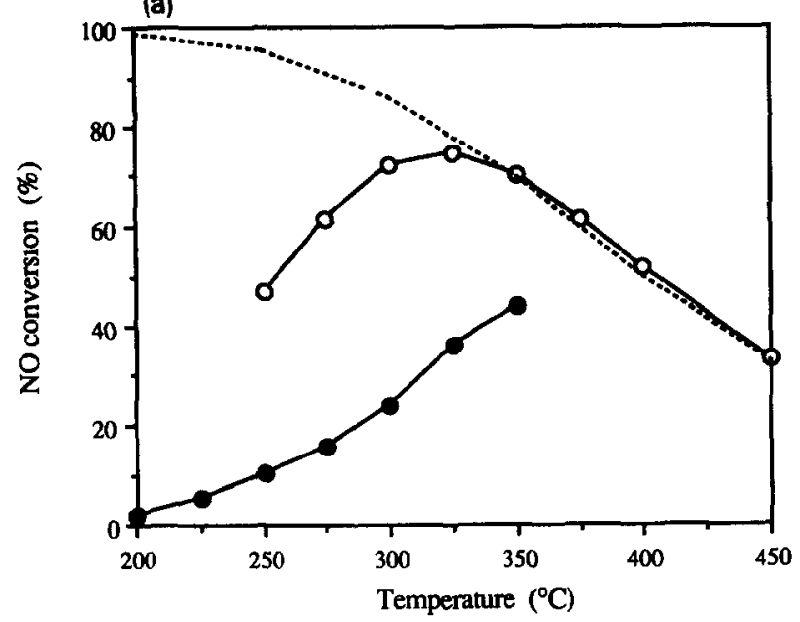

(b)

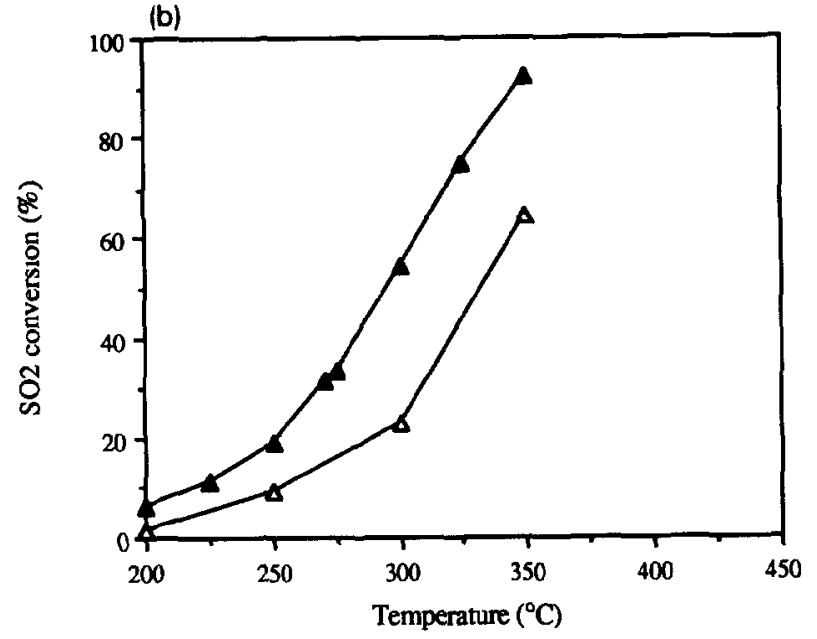

Fig 2 (a) Nitnc oxide conversions over EuroPt-1 catalyst in the presence/absence of sulphur dioxide (-....) Equilibrium conversion, $(\mathrm{O})$ in the absence of $\mathrm{SO}_{2},(O)$ in the presence of $\mathrm{SO}_{2}$ (b) Sulphur dioxide conversions over EuroPt-1 catalyst in the absence/presence of nitric oxide $(\Delta)$ In the absence of NO, $(\Delta)$ in the presence of NO

of nitric oxide could enhance sulphur dioxide oxidation This mutual influence of nitric oxıde and sulphur dioxıde is more pronounced over platınum catalyst, while it is less significant over the $\mathrm{SiO}_{2}$ support (see Table 1) or in the absence of a catalyst

Interactions among $\mathrm{NO}_{x}$ sulphur doxide and oxygen over the catalyst

To investigate the nature of the interactions between $\mathrm{NO}_{x}$ and sulphur diox- 
Ide over the catalyst, a series of experiments was carried out in which the feed gas composition was changed periodically and the product gas concentrations were analyzed continuously Results of a typical run at $300^{\circ} \mathrm{C}$ is shown in $F_{1} g$ 3 , in which the events of operation are also indicated at the top of the figure The catalyst had been reduced before the experiment started In this experiment a gas stream with $\mathrm{N}_{2}+\mathrm{SO}_{2}\left(\mathrm{SO}_{2} 100 \mathrm{ppm}\right)$ first bypassed the reactor and went directly to the sulphur dioxide analyzer until the output signal of sulphur dioxide from the analyzer was stabilized at $100 \mathrm{ppm}$ (level A) The catalyst was heated in nitrogen to the desired temperature, in this experiment $300^{\circ} \mathrm{C}$, and the gas stream was switched from the bypass to the reactor A rapid decrease of the sulphur dioxide signal was recorded, followed by an increase and stabilization at another constant level (level B) The initial rapıd drop of sulphur dioxide signal may correspond to the adsorption of sulphur dioxide on the catalyst The fact that the sulphur dioxide level did not return to the original value is probably due to the oxidation of some of the sulphur dioxide by oxygen present as an impurity in nitrogen carrier gas (about $25 \mathrm{ppm}$ ) When the feed gas was switched to the bypass again, the sulphur doxide signal increased back to the original level of $100 \mathrm{ppm}$

$100 \mathrm{ppm}$ NO was also now added to the gas stream in the bypass mode The nitric oxide signal increased from 0 to $84 \mathrm{ppm}$ and remained constant That the level did not reach $100 \mathrm{ppm}$ was probably due to the oxıdation of nitric
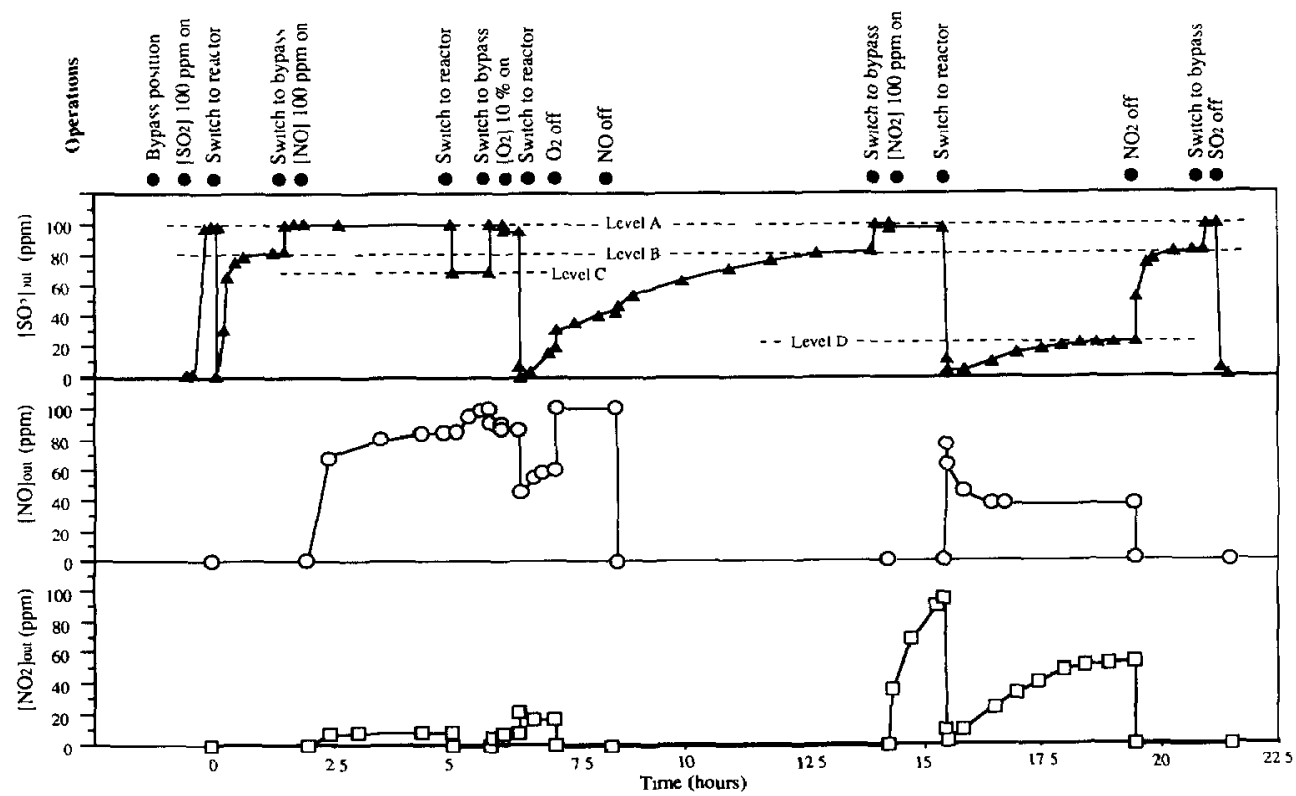

Fig 3 The changes in concentrations of sulphur dioxıde, nitric oxide and nitrogen dioxıde recorded under different operation conditions 
oxide to nitrogen dioxide with the oxygen impurity present in nitrogen carrier gas (about $25 \mathrm{ppm}$ ), this reaction may have been catalyzed by the stainless steel piping in the system That this reaction is takıng place can also be seen from the increase and stabilization of the nitrogen doxide signal The sulphur dioxide signal remained constant at the $100 \mathrm{ppm}$ level, indicating the absence of gas-phase reactions between the $\mathrm{NO}_{x}$ and the sulphur dioxide

When the mixed gas $\left(\mathrm{NO}+\mathrm{SO}_{2}\right)$ was then introduced to the reactor, the sulphur dioxide signal output dropped to a new level (level C), which was lower than that (level B), which was measured under similar conditions, before nltric oxide introduction The nitric oxide signal increased at the same time and reached a constant level of $100 \mathrm{ppm}$ Both the above observations are indicative of the reaction between nitrogen dioxide and sulphur dioxıde over the catalyst according to

$\mathrm{NO}_{2}+\mathrm{SO}_{2} \rightarrow \mathrm{NO}+\mathrm{SO}_{3}$

The gas stream was then switched to bypass and oxygen (10 vol -\%) was added to it The stream ( $\mathrm{NO}+\mathrm{SO}_{2}+\mathrm{O}_{2}$ ) was then switched to the reactor again and the sulphur dioxide signal first dropped to zero and then started to rise slowly Subsequent switching off of first the oxygen and then the nitric oxide progressively helped the sulphur dioxide signal to come slowly back to level B The corresponding change in nitric oxide signal is also shown in Fig 3 The change in sulphur dioxide and nitric oxide concentrations is an indication of the oxidation of sulphur dioxide by oxygen as well as by nitrogen dioxide but also that of nitric oxide by oxygen

The gas stream was switched to the bypass and nitrogen dioxide (100 ppm) was added to the feed before switching to the reactor. This made the sulphur dioxide signal to drop first to zero and then rise to a steady level (level D) Switching nitrogen dioxide off brought the sulphur dioxide back again to level $B$ The corresponding changes in nitric oxide and nitrogen dioxide can also be seen in the figure This is also a direct indication of the reaction over the catalyst between nitrogen dioxide and sulphur dioxide according to the equation $\mathrm{NO}_{2}+\mathrm{SO}_{2} \rightarrow \mathrm{NO}+\mathrm{SO}_{3}$

Temperature-programmed desorption and temperature-programmed reduction

The NO/ $\mathrm{SO}_{2}$ adsorption/desorption behaviour of the platınum catalyst under the experimental conditions has been studied by means of TPD exper1ments and the results are shown in Figs. 4a and b, respectively Fig 4a shows data for the TPD of $\mathrm{NO}_{x}$ after pre-treatment of the catalyst with $\mathrm{NO}+\mathrm{N}_{2}$ or $\mathrm{NO}+\mathrm{SO}_{2}+\mathrm{N}_{2}$ It can be seen that the presence of sulphur dioxide in the feed gas influences the adsorption/desorption of nitric oxide and nitrogen dioxide on the catalyst, the desorption peaks of nitric oxıde and nitrogen dioxıde shift to higher temperatures and become broader when the pre-treatıng gas contains 

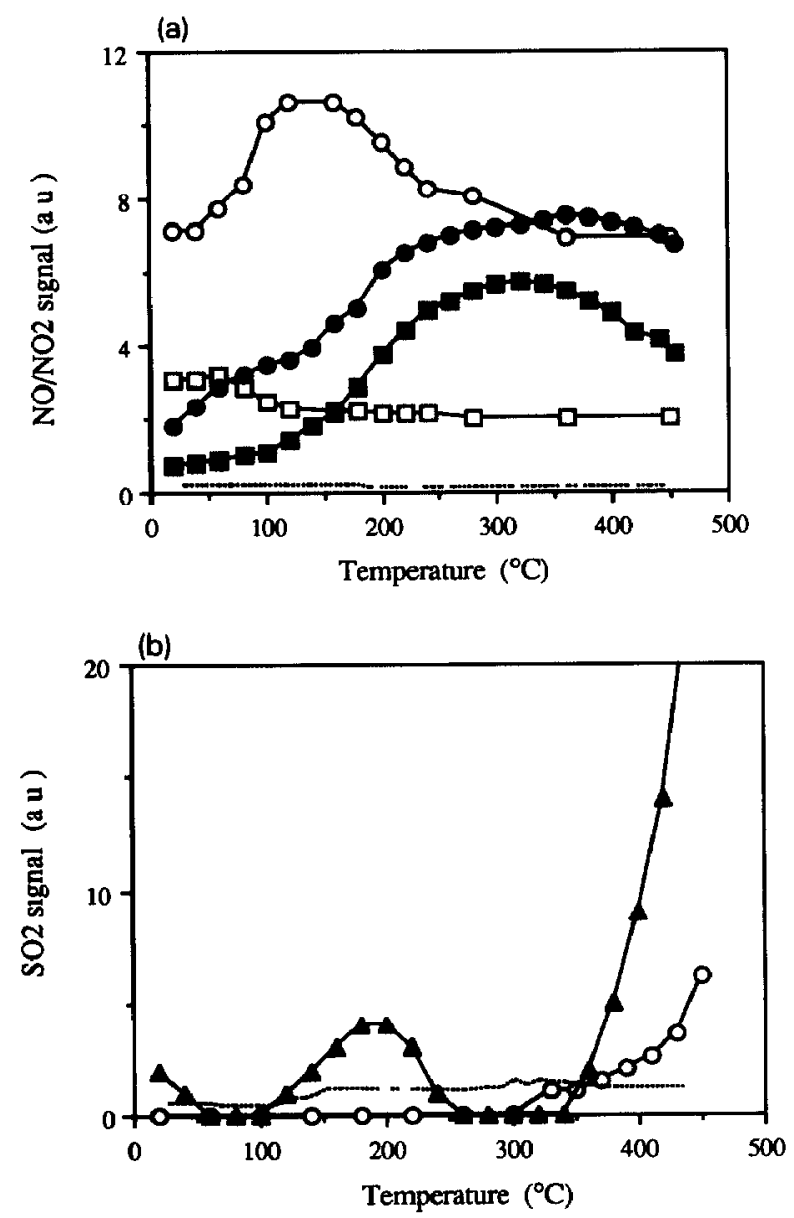

Fig 4 (a) TPD of $\mathrm{NO} / \mathrm{NO}_{2}$ over EuroPt-1 catalyst after different pretreatments (O) NO signal, pretreated with $\mathrm{NO}+\mathrm{N}_{2}$, (O) $\mathrm{NO}$ signal, pretreated with $\mathrm{NO}+\mathrm{SO}_{2}+\mathrm{N}_{2}$, ( $\square$ ) $\mathrm{NO}_{2}$ signal, pretreated with $\mathrm{NO}+\mathrm{N}_{2}$, ( $) \mathrm{NO}_{2}$ signal, pretreated with $\mathrm{NO}+\mathrm{SO}_{2}+\mathrm{N}_{2},\left(\right.$ ) $\mathrm{NO}$ and $\mathrm{NO}_{2}$ signals over $\mathrm{SiO}_{2}$, pretreated with $\mathrm{NO}+\mathrm{SO}_{2}+\mathrm{O}_{2}$ (b) TPD of sulphur dioxide in nitrogen over EuroPt-1 catalyst after different pretreatments, (O) $\mathrm{SO}_{2}+\mathrm{N}_{2},(\Delta) \mathrm{SO}_{2}+\mathrm{NO}+\mathrm{N}_{2},($ ) support $\mathrm{S}_{1} \mathrm{O}_{2}$, pre-treated with $\mathrm{SO}_{2}+\mathrm{NO}+\mathrm{O}_{2}$

sulphur dioxide On the other hand, when the catalyst was pre-treated with $\mathrm{SO}_{2}+\mathrm{N}_{2}$ or $\mathrm{SO}_{2}+\mathrm{NO}+\mathrm{N}_{2}$, an additional sulphur dioxide desorption peak showed up at lower temperatures, the sulphur dioxide desorption peak at high temperature also became much greater on the catalyst which had been pretreated with the nitric oxide-containing gas (Fig $4 \mathrm{~b}$ ) The results of TPD measurements over the pure $\mathrm{S}_{1} \mathrm{O}_{2}$ are also shown as dotted lines in Figs $4 \mathrm{a}$ and $\mathrm{b}$, the effect of the support on the adsorption/desorption of $\mathrm{NO}_{x}$ and sulphur dioxide appears to be insignificant 
The TPR measurements of the catalyst after various pre-treatments are shown in Fig 5. The type of pretreatment given is shown in the figure. (The reduced catalyst mentioned in the figure refers to the catalyst which had been reduced in a gas stream of $5 \% \mathrm{H}_{2}$ in $\mathrm{Ar}$ at $490^{\circ} \mathrm{C}$ before any other treatment) It can be seen from the figure that the fresh, clean catalyst (curve a) shows a single reduction peak at around $100^{\circ} \mathrm{C}$ When the reduced catalyst was treated with nitric oxide before TPR (curve c) one additional peak appeared at around $310^{\circ} \mathrm{C}$. The reduced catalyst when treated with sulphur droxide before TPR (curve d) showed one peak around $150^{\circ} \mathrm{C}$ When the catalyst was oxidized (at $490^{\circ} \mathrm{C}$ ) before sulphur dioxıde pretreatment (curve e) it showed two reduction

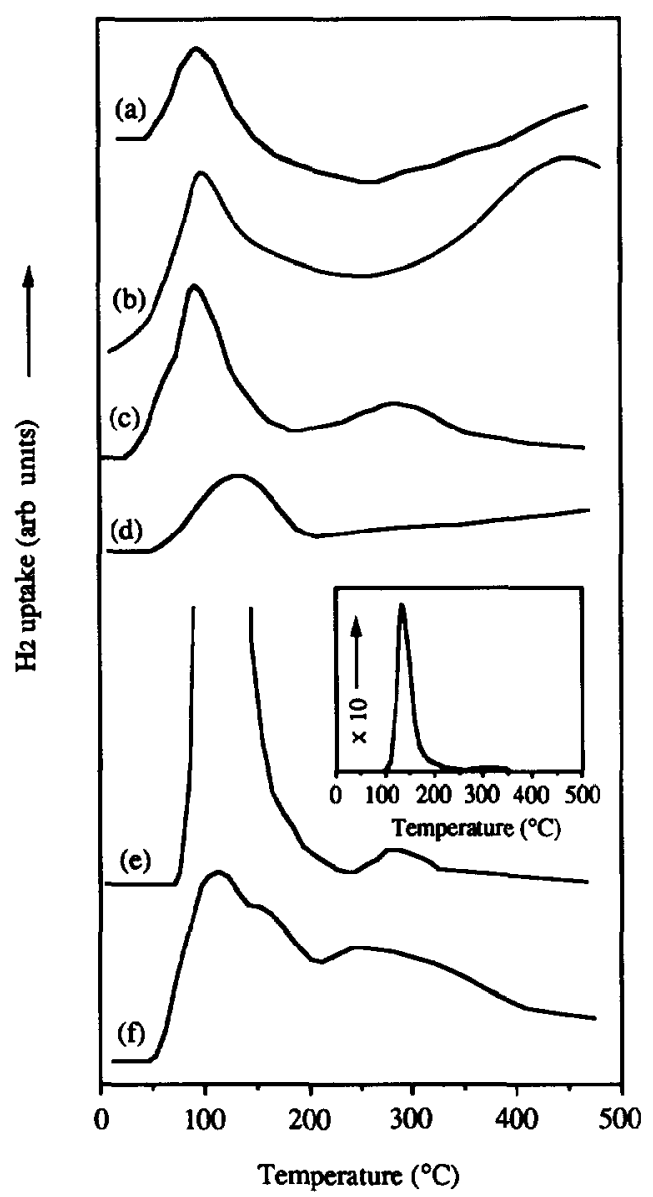

Fig 5 TPR patterns recorded over EuroPt-1 after different treatments (a) fresh, (b) used for activity test, (c) reduced, after being treated with NO, (d) reduced, after being treated with sulphur dioxıde, (e) oxidısed after being treated with sulphur dioxıde, (f) reduced after being treated with nitric oxıde then sulphur dioxıde 
peaks at $150^{\circ} \mathrm{C}$ and $310^{\circ} \mathrm{C}$, respectively (The low-temperature peak was significantly larger than that on the reduced catalyst after adsorption of sulphur dioxide) When the reduced catalyst was treated with nitric oxide and then sulphur dioxide before TPR (curve f), a complex reduction pattern showing at least three peaks was observed It is interesting to note from the figure that the third reduction peak in the curve (f) (pre-treatment of the reduced catalyst with $\mathrm{NO}+\mathrm{SO}_{2}$ ) is relatively much broader compared to the peaks at around $300^{\circ} \mathrm{C}$ in the curve (c) (pre-treatment of the reduced catalyst with nitric oxide) and the curve (d) (pre-treatment of the reduced catalyst with sulphur dioxide)

Considering the observations that nitric oxide affects the TPD pattern of sulphur dioxide and that the presence of sulphur dioxide changes the TPD pattern of $\mathrm{NO} / \mathrm{NO}_{2}\left(\mathrm{~F}_{1}\right.$ gs $4 \mathrm{a}$ and $\left.\mathrm{b}\right)$ as well as the observation that the TPR pattern over the reduced catalyst after treated with nitric oxide and then sulphur dioxide is different from those over either the reduced or oxıdızed catalyst when treated with either nitric oxide or sulphur dioxide (Fig 5), it would appear that some sort of complex surface species (e $\left.g\left[\mathrm{~N}_{x}-\mathrm{S}_{y}-\mathrm{O}_{z}\right]\right)$ is present on the catalyst when both nitric oxide and sulphur dioxide are co-adsorbed on the catalyst The interaction between $\mathrm{NO}_{x}$ and sulphur dioxide may occur via this complex surface species

\section{Effect of oxıdation treatment}

Oxidation treatment of a fresh catalyst at $500^{\circ} \mathrm{C}$ in air was observed to increase temporarily the activities for the oxidation of both nitric oxide and sulphur dioxide, however, after a few temperature cycles, the actıvitıes returned to the level of activity of the fresh catalyst (Fig 6) It has been reported earlier

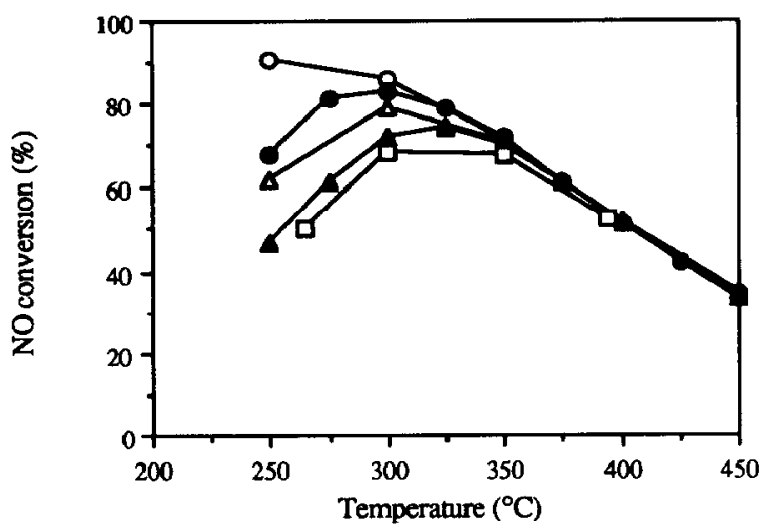

Fig 6 Nitric oxide conversions over the oxidised EuroPt-1 in four cycles of the activity test, as compared with the fresh catalyst $(O) 1$ st cycle, $(O)$ 2nd cycle, $(\Delta) 3$ rd cycle, $(\Delta)$ th cycle, (ㅁ) fresh EuroPt-1 
that EuroPt-1 showed no change in the particle size distribution when it was heated in air at temperatures up to $527^{\circ} \mathrm{C} \mathrm{[5}$ ]. It is probable that the oxidation treatment may give nise to some sort of oxygen species on the catalyst surface on which the oxidation of both nitric oxide and sulphur dioxide could easily take place Another possibility would be that a rearrangement of platınum atoms occurs on the catalyst surface durng the oxygen treatment and this may lead to increased activity for the oxidation of nitric oxıde and sulphur dioxide Further experimentation would be necessary to explain this observation

\section{Deactivation}

The catalyst was observed to deactivate rapidly at the beginning of the activity test, and then to become stabilized in subsequent runs (see data for the fresh and used catalysts in Table 1) Reduction of the used catalyst in hydrogen at $400^{\circ} \mathrm{C}$ brought about only a partial recovery in the activities for both nitric oxide and sulphur dioxıde oxıdation, however, the activities dropped quickly back to levels similar to those before reduction (see Table 1) Comparing TPR patterns of the fresh and used catalysts (curve $a$ and $b$ in Fig 5) there is an extra peak that appears around $450^{\circ} \mathrm{C}$ in the case of the used catalyst This species probably corresponds to the higher-temperature desorption peak in the TPD patterns in Fig 4b As this high-temperature desorption peaks did not show up in the TPD measurement over a pure $\mathrm{SlO}_{2}\left(\mathrm{~F}_{1} \mathrm{4b}\right)$, this species, formed in the reaction gas mixture, is probably adsorbed on the platinum sites, causing the catalyst deactivation X-ray photoelectron spectroscopy (XPS) measurements showed the existence of some sulphur- and nitrogen-containing species on the surface of the catalysts after use (F1g 7) These strongly adsorbed surface species could be removed, at least partially, by higher-temper-

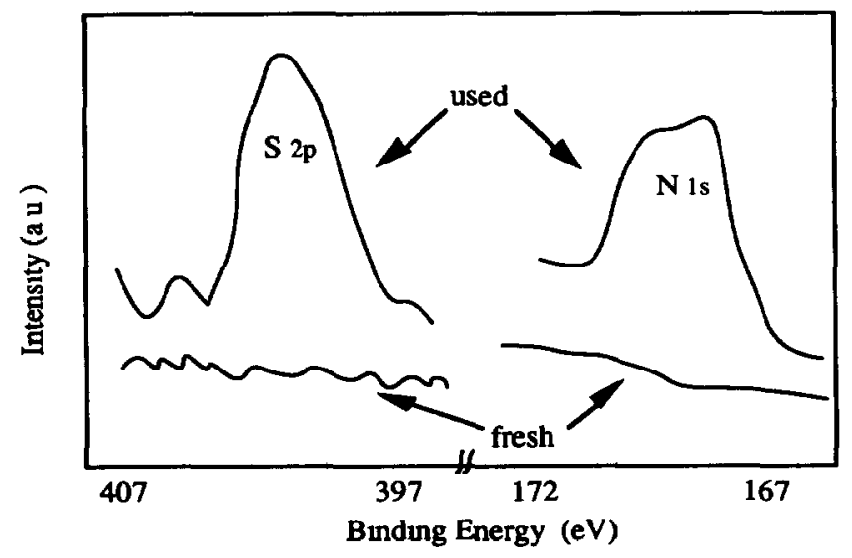

Fig 7 XPS results of fresh and used EuroPt-1 catalysts 
ature treatment with hydrogen (curve b in Fig. 5), however, they easily reformed when the catalyst was contacted with nitric oxide and sulphur dioxide under the reaction conditions This may be the reason why the reduction treatment (at $400^{\circ} \mathrm{C}$ ) of the used catalyst could only partially recover the activity and the activity dropped again in a short penod after the catalyst was exposed to the reaction gas mixture (Table 1) From these observations we conclude that the deactivation of the catalyst is related to the existence of some sort of strongly adsorbed species which sits on the platinum surface and blocks the active sites of the platinum The low-temperature peak in TPR of the used catalyst (curve b, Fig 5) also shifted to a higher temperature and became broader compared to the fresh catalyst (curve a, in Fig 5) This change in the reduction characteristics of the catalyst after use may also be related to the change in activity of the used catalyst

To investigate other possible causes of the catalyst deactivation, the plat1num dispersion of the fresh and used catalysts was examined A decrease of $23 \%$ in the platinum dispersion on the used catalysts was found (the platinum metal surface area measured: the fresh catalyst $772 \mathrm{~m}^{2} \mathrm{~g}^{-1}$, the used catalyst $595 \mathrm{~m}^{2} \mathrm{~g}^{-1}$ ) This decrease in the platınum dispersion may also contribute towards the deactivation The loss of platinum dispersion could be caused by sintering of the surface platinum particles in the reaction environment It has been reported that a $\mathrm{HCl}$ treatment followed by calcination in air could increase platınum dispersion in supported platınum catalysts [13] In our case, however, $\mathrm{HCl}$ treatment (see Experimental) of the used catalyst showed a negative effect on sulphur dioxıde conversions when the experiments were carried out with ether $\mathrm{SO}_{2}+\mathrm{O}_{2}$ or $\mathrm{SO}_{2}+\mathrm{NO}+\mathrm{O}_{2}$ (see data for Cl-used catalyst in Table 1) This could be due to the pronounced poisoning effect of $\mathrm{HCl}$ on the sulphur dioxide oxıdation actıvity of platınum catalysts [14] In the case of nitric oxıde oxidation, however, the $\mathrm{HCl}$ treatment showed a different feature it inhibited nitric oxide oxidation when the feed gas contained only $\mathrm{NO}+\mathrm{O}_{2}$, however, when the experiments were performed with the feed gas $\mathrm{NO}+\mathrm{SO}_{2}+\mathrm{O}_{2}$, it promoted the oxidation of nitric oxıde (see Table 1) Thus the selectivity of the catalyst for the oxidation of nitric oxide over sulphur dioxide was improved The mechanism for the effect of $\mathrm{HCl}$ treatment on the oxıdation of nitric oxıde over EuroPt-1 is not yet clear

\section{CONCLUSIONS}

(1) Gas-phase interactions between nitric oxide, sulphur dioxıde and oxygen occur only to a small extent under the conditions concerned (2) The EuroPt1 catalyst is very active for oxidation of both nitric oxide and sulphur dioxide (3) There is a significant mutual influence between nitric oxide and sulphur dıoxide, 1 e the presence of sulphur dioxide suppresses nitric oxide oxidation while the presence of nitric oxide enhances sulphur dioxide oxidation, there is 
a significant influence of nitrogen dioxide on sulphur dioxide oxidation; there are also indications that some sort of surface species (e.g. $\left.\left[\mathrm{N}_{x}-\mathrm{S}_{y}-\mathrm{O}_{z}\right]\right)$ is formed on the platinum surface. (4) The catalyst undergoes deactivation during activity test, probably due to the build-up of strongly adsorbed N- and S-compounds on the catalyst surface and the loss of the platinum dispersion (5) $\mathrm{HCl}$ treatment of the catalyst increased the selectivity of the catalyst for the oxidation of nitric oxide over sulphur dıoxide

\section{ACKNOWLFDGEMENT}

Authors would like to thank Johnson Matthey PLC for partial financial support of this work

\section{REFERENCES}

1 ES Lox, B H Engler and E Koberstein, in A Crucq (Editor), Catalysis and Automotive Pollution Control II (Studies in Surface Science and Catalysıs, Vol 71), Elsevier, Amsterdam, 1991, p 291

2 B J Cooper and S A Roth, Platinum Metals Rev , 35 (1991) 178

3 A F Ahlstroem and C U I Odenbrand, Appl Catal , 60 (1990) 157

4 C J Dettling and R Skomoroski, Eur Pat Appl, EP 160482 (1985)

$5 \quad$ P B Wells, Platınum Metals Rev , 29 (1985) 168

6 J Prasad, K R Murthy and P G Menon, J Catal, 52 (1978) 515

7 J C Hilliard and R W Wheeler, Combust Flame, 19 (1977) 15

8 J K Dixon and J E Longfield, in W W Duecker and J R West (Editors), The Manufacture of Sulfuric Acıd, Reinhold, New York, 1959, p 135

9 J C Summers and K Baron, J Catal , 57 (1979) 380

10 H T Kansson and H S Rosenberg, Ind Eng Chem Process Des Dev , 23 (1984) 808

11 Y Teraoka, K Shimanoe and N Yamazoe, Chem Lett , (1987) 2047

12 H Ara1, H Tomınaga and J Tsuchiya, in G C Bond, P B Wells and F C Tompkıns (Edıtors), Proceedings 6th International Congress on Catalysis, London, 12-16 July 1976, Vol 2, The Chemical Society, London, 1977, p 997

13 H Lieske, G Lietz, H Spindeler and J Volter, J Catal , 81 (1983) 8

14 T J P Pearce, in G Nıckless (Editor), Inorganıc Sulphur Chemıstry, Elsevier, Amsterdam, $1968, \mathrm{p} 535$ 